Journal of Social Sciences 6 (2): 221-228, 2010

ISSN 1549-3652

(C) 2010 Science Publications

\title{
The Importance of Information through Accounting Practice in Agricultural Sector-European Data Network
}

\author{
Vazakidis Athanasios, Athianos Stergios and Ekaterini C. Laskaridou \\ Department of Applied Informatics, University of Macedonia, \\ 156 Egnatia Street, P.O. Box 1591, 54006 Thessaloniki, Greece
}

\begin{abstract}
Present study investigated the gap between accounting practices and the magnitude role of accounting information in the agricultural sector. Problem statement: Factors for this gap are: Current general accounting rules do not reflect the particularities of farming, the need of farm management, rural development and sustainability. The introduction of International Accounting Standard 41 (IAS 41) by International Accounting Standard Committee, Approach: With the Farm Accounting Data Network (FADN) in Europe, could be key elements to improve the use of agriculture accounting. Results: After mandatory and optional adoption for listed and non-listed small size companies, of IAS's respectively, by EU at 2005, we conclude that the main contribution of IAS 41 is to provide a strong conceptual framework in agricultural accounting practice. Conclusion: FADN is an experienced data network, which could be a guide for implementing of IAS 41. Finally, we unfold IAS 41 statutory and FADN procedures grounding an informative frame for farm development policy.
\end{abstract}

Key words: Agriculture, IAS 41, FADN, farm accounting

\section{INTRODUCTION}

In spite of its relative importance in the Greek economy, agriculture does not receive as much attention from accounting researchers, practitioners and standard setters. As an example, until the arrival of IAS 41 in February 2001 there was no standard anywhere for biological assets, whose valuation is difficult and controversial.

In terms of causality, the generally lower level of managerial sophistication, lack of economic means in the sector and the limited appropriateness of general accounting principles have led to inefficient agroinformative panel. Farmers have been more reluctant to prepare accounting reports. Moreover, because of their size or legal form, most European farms have no legal obligation to publish financial statements (farm typology). Farmers usually prepare accounts in order to comply with tax framework and subsidies.

On the other hand, it is generally believed that accounting can improve farm management and lead to better performance (Luening, 1989; Allen, 1994) funding sources (other than subsidies) also are more easily achieved. Furthermore, the accounting procedures make significant contribution to prediction and explaining farm failure (Argiles and Slof, 2001). Policy makers have also a need for accounting information as precondition for decision making, explaining and predicting farm failure (Tonea, 2001).

In the Europe context of rural development the Common Agriculture Policy (CAP) has been one of the cornerstones of the economic and political integration process. The European Commission by FADN had to make efforts to obtain standardized information. In terms of account income statistics for household farms no aggregate data are available in the FADN/RICA database. So this implies that existing data may undermine the quality of income accounts for any established statistical source posed on EU agriculture policy.

In this study we provide some suggestions to assessing the gap between the low level of accounting practice used and the importance of accounting information in agricultural sector. We believe that the complementary exploitation of two already existing tools, IAS's and FADN, can have leading role.

The agricultural activity is very heterogeneous with inherent great diversity. The lack of normalization with economic pressure for viable policies (second pillar, CAP) reveal the need for financial information, on the ground farms' performance.

Traditionally Greece is economically focused on agricultural activity associated with small or medium size farms, with the main objective to add family

Corresponding Author: Vazakidis Athanasios, Department of Applied Informatics University of Macedonia, 156 Egnatia Street, P.O. Box 1591, 54006 Thessaloniki, Greece Tel: +302310891863 


\section{J. Social Sci., 6 (2): 221-228, 2010}

income. Last decade mainly of increasing commercialization, agricultural activity pictures great importance as contributes $7 \%$ of the national GDP with an annual value of 16 euro billion. The sector also employs almost $20 \%$ of the Greek workforce. The National Framework of the new re-structuring programming period (2007-20013) coincided with the principles of the reformed Common Agricultural Policy (agenda 2000 CAP) focuses on the reinforcement of all three pillars of sustainable development, (economic, social and the environmental). The planning relies on a mixed "top down" pattern. There is a wide participation in the process of social and economic factors on the basis of integrated strategies for land areas (programming micro-regions) with distinct geographical entities. However these strategies ignore any associated accounting policy granting consequently deficient accounting information.

Historically Greek farm modernization is outlined on a certain set of agri-environmental incentives (Karanikolas and Martinos, 2007).

Rezitis et al. (2002) report that in 1993, the farm labor force was about $21.9 \%$ of the total labor force in Greece $(5.9 \%$ in the EU-15) and the gross value added at factor costs by agriculture, forestry and sherries was about $13.7 \%$ (2.8\% in the EU-15). In the same year, the average Utilized Agricultural Area (UAA) per holding, in Greece, was about 4.3 ha (16.4 ha in the EU-15).

Furthermore, about $75.7 \%$ of all holdings were in the size class of less than 5 ha $(56.8 \%$ in the EU-15), while only about $0.39 \%$ was in the size class of more than 50 ha $(7.3 \%$ in the EU-15). Although, the average size of Greek holdings, expressed in UAA, is only about $1 / 4$ of the average size of EU holdings, the average economic size of holdings is about $1 / 2.4$ the reason is the high proportion of various intensivefarming activities in Greek agriculture (i.e., greenhouses, vegetables, tobacco and stabling cattlebreeding). Over all, the ratio of plant to livestock production (70: 30) continues to be almost reversed to that of the average Community (50: 50) (Pavlos, 2004a; 2004b).

In a recent study by the National Agriculture Research evidence reveal the uniqueness of Greek agriculture compared to average Europe cultivating ratios with farm holding income.

Through reasoning of Greece's particularities three fundamental characteristics can lay down:

- Many farms are based on small-sized familyowned dispersed units, with limited training in accounting and finance the double-entry record system is predominantly focused on a cash basis with periodic generation of financial statements. while the extent of cooperative organization stays at low comparative levels, against all efforts that have been taken in the last 30 years, mainly under EU policy

- Because of the narrow capabilities of farm record keeping systems, lenders are forced to focus their analysis on the information that can reasonably be obtained from the farmers. Since few noncash transactions (e.g., perpetual inventories, charge-off of prepaid, accrual of liabilities) are recorded by the farmer, a cash-based system is the primary source of information on net cash income

- The lower level of accounting sophistication with primary focus in the tax-driven accounting frame as the most farms have legal obligations to prepare accounting reports on the basis of tax and subsidy requirements (agents in other economic sectors)

Olsson (1988) and Allen (1994) make clear that limited use of accounting in agriculture on account of shortcoming accounting skills by farmers, regarding the predominance of the small family farm even in the agricultural production of highly industrialized Western countries. Poppe (1991) and Poppe and Breembroek (1992) also lay out some defaults of agriculture information. Kroll (1987) and Andre (1987) point out that when French farmers use accounts, it is primary to comply with tax and subsidy requirements. Colwell and Koroluk (1990) set the predominance of an informal cash bookkeeping system as the most common accounting method used in Canada even if this does not present a fair performance of the farm. Seger and Lins (1986) present similar outcomes in the USA. Bronstien (1995) and Crane and Leatham (1995) consider standardized accrual accounting necessary for the growth rate of agricultural entrepreneurship in the USA. In France and the European Union (EU) tax related to economic schemes encourage authorities to promote the use of accounting in agriculture (Pellerin, 1985).

The prevailing held view is that accounting information can improve farm management (financial leverage ,forecasting, farm viability), providing that the employed accounting reports are consistent with agroeconomic data and sustainable-logic plans, are also consonant with CAP and Ministry's Agriculture Policy. So the option of uniform approach with harmonized statistics in Agriculture sector, seem to be prime principle for the farm community.

Within context of observation and identification of multifunctional-harmonized network with indicators of farm outputs researchers as (Psaltopoulos and Balamou, 


\section{J. Social Sci., 6 (2): 221-228, 2010}

2005) propose sophisticated data models, either on the basis of dynamic DSS with agro-economic data (LENNART) or multi-sectoral function basis as Social Accounting Matrix (SAM) analyzing economic effects of rural development policies. Further Rezitis et al. (2002) study indicated that any substantial improvement in technical efficiency of Greek farms is integrated to rural education concerning also the need for extensive cross-sectional data. All above are parts of efforts to generate practical tools introducing sophisticated accounting know-how with technology.

Farmers are reacting to rural development plans by diversifying from farming into other activities partly farming. The long term sustainability with profitability in agricultural and rural policy should be revalued on the broadness of micro economic data, as function of farm accountancy data networks (Poppe, 2005).

It is of concern that there is not reference for homogenous objectives between any national informative network and FADN created in the context of Common Agriculture Policy (CAP). Published surveys on Greek agriculture activity merely utilize FADN data without farther validating process. Moreover the forces primarily define the accounting reporting is the agriculture lending community with official government and financial analysts. These groups are not subjected to any formal frame at consistency and standardization.

So considering the magnitude of demand for accounting information in agriculture, we unfold two existing tools: (1) IAS 41 released by IASC changed agricultural accounting from a domestic issue to a global issue. As part of international harmonization, International Financial Reporting Standards (IFRS) are to be adopted by all listed companies within the European Union from January 2005. (2) The European Union's Farm Accountancy Data Network (FADN) determined to evaluate the farm income and support the on-farm decision making process. We estimate that these parallels system-set can forward and strengthen the accounting information and make it inherently operational.

IAS 41 agriculture: Under IAS 41, biological assets relating to agricultural activity are to be measured at fair value less estimated point-of-sale costs on initial recognition and at each reporting date. Gains or losses on initial recognition and from a change in fair value of a biological asset are to be included in profit or loss for the period in which they arise. In addition, a gain or loss on initial recognition of agricultural produce harvested from a biological asset less point-of-sale costs is to be included in profit or loss for the period in which it arises.
An unconditional government grant related to a biological asset is recognized as income when the grant becomes receivable while a conditional government grant is recognized when the conditions attaching the grant are met.

IAS 41 bear distinct definition for Biological Assets defined as living animals and plants that are controlled as result of past events and agriculture produce

IAS 41 define whenever a biological asset fair value can be measured reliably, the entity should measure the biological asset on initial recognition and at each balance sheet date at its fair value less the estimated point-of-sale costs (IASC, 2000).

There are two main issues of concern-the measurement of biological assets at fair value and the recognition of changes in fair value of biological assets -unrealized gains or losses-as part of income at each reporting date.

Fair value: Fair value is asserted to be more relative and faithfully depict the reality of biological transformation. Opponents have turn on the practical difficulties arising from valuing biological assets for which there are no active and liquid markets. In these cases establishing fair values may show to be excessively costly, particularly in developing countries (Argiles and Slof, 2001; Elad, 2004). Also, the subjectivity in assessing of fair value reduces the reliability of reported information and gives scope for manipulation Furthermore there are practical difficulties in valuing biological assets separately from related assets such as the land on which they are located, study making by Booth and Walker (2003) was highly critical on this point. Generally the approach of IAS 41 remains academic and not focused on the practical issues. This generates potential undermining information.

Unrealized gains or losses: Eventually the most criticized requirement of IAS 41, arises from unrealized gains or losses accrued changes in the fair value of biological assets measured at reporting date in income. Proponents argue it reflects the efforts of managements' handling of the biological assets over the period, more precisely to the 'percentage-of-completion' revenue recognition method for long-term construction contracts (Argiles and Slof, 2001; Elad, 2004). However, critics hold that there is too much uncertainty regarding the material realization of the revenue. This is probably the case for biological assets with longer production cycles such as forests and grape vines used to produce fortified wines. The recognition of profits that are not realized for several years may also lead to misleading expectations of 
distributable profits amongst shareholders, in turn provoking pressure for entities to declare and pay dividends for which no funds are disposable. Additionally, recognition of unrealized gains or losses increases the volatility of reported income.

Alternative measurements: In case of no existent market the first choice would be a market-determined price as the most recent market price for specific classsimilar of asset (IAS 41:18). If there isn't market available, the present value of expected net cash flows from the asset should be discounted at a current market rate (IAS 41:20). The cost price is an indicator of the fair value used to approximate it (IAS 41:24).

IAS 41 in balance sheet: The nature and stage of production of each group-biological asset should be depicted in narrative format in the disclosure in the financial statements. Consumable assets (are assets themselves to be harvested e.g., fattening pigs) should be distinguished from bearer assets (vineyards) with further sub-classification into mature (assets that harvestable or able to sustain regular harvest) and immature sub-grouping each of these in order to provide some insight into the timing of future cash flows (Epstein and Mirza, 2003; Burnside, 2005). Potential on-going changes on assets' fair value affect the balance sheet state since both increases and decreases affect equity amount while several ratios are subsequently affected by these changes.

IAS 41 in income statement: In all changes fair value should be presented on the face of the income statement visibly broken down groups of biological assets (Epstein and Mirza, 2003; Burnside, 2005).

Generally IAS 41 is a very useful document for accountants providing an excellent framework to improve accounting issues. However the IAS 41 itself cannot overcome barriers that arise from implementation issues or managerial limitations. We believe that its implementation with optionalmechanism tools could elaborate accounting practices on the context of effectiveness. Further the standard seems to be helpful for economists and statisticians that operate internationally. So the use of the standard should be encouraged even in tax law environment as it indirectly influences universities, banks and accounting organizations (Poppe, 2000).

Key features of the Farm Accounting Data Network (FADN): The European Union manages a separate, information system in order to gather information about agriculture activity. Farm Accountancy Data Network
(FADN) is a network that gathers representative data about agricultural holdings from all the EU member states. The scope of the network is to gather accountancy data from farms for the determination of financial performance, to prepare a business analysis of agricultural holdings, to measure the impact of the EU's agricultural policy.

Reliability of data published by FADN strongly depends on the farmers that provide information to the network (Csajbok, 2009). If FADN can provide information, reports to the agricultural holdings in the network that have positive effect on the farms; this could significantly improve the accuracy and motivation of data providers and their belief in the network. Accordingly, FADN has to put extra emphasis on the appropriate quality of content information in order to feed farmers on timing as well, to ensure that farmers can utilize these data in their own microenvironment.

The Greek network strongly depends on the agricultural holdings taking part in the network. In order to ensure the reliability of information from agricultural holdings it is important farmers to participate in the network actively. Moreover the rotation of the sample combined with no bench-marking others farm reports (bank statements) unfair the value of data.

Complete documentation of FADN can be found in CEC (1997; 1998). Its main characteristics can be summarized in the following points:

- FADN aims to collect accounting data on the performance and income of farms in the EU

- FADN data are not obtained at a macro-economic level, but from a random rotating sample of approximately 70.000 individual farms across all member states

- The field of observation of FADN is that of "commercial" farms. A minimum European size unit is established in each member state to define the commercial farm

- The sample is stratified by region, farm size and type of farming (commercial farm threshold)

- The sample is a network of networks of accounting offices. The accounting offices are not similar between the member states. Some are commercial accounting offices that adapt records already kept for tax purposes or investment aids. In other countries the accounts are prepared by research institutes, universities or agricultural official authorities (agriculture ministry). Many of the accounting office's only keep these records for the purpose of FADN

The collected data are transmitted to regional committees and from there to the national liaison 
offices. The national liaison offices then forward them to the European Commission in Brussels, where FADN's management committee checks the validity of the data and stores them in a database.

Depending on the country, either the regional committees or the national offices select the sample for a given stratification. However, the final sample is always conditioned by the participation of the farmers, which is voluntary.

FADN data are confidential, so these cannot be disclosed or used for tax purposes. Therefore, a minimum number of farms are required for each stratum to assure anonymity. FADN never publishes nor otherwise provides information about individual farms.

FADN data are collected through a questionnaire, the "Farm Return," from a variety of sources, such as bank statements and invoices. The Farm Return is the core of the FADN data collection procedure and is filled out by the farms with the assistance of the accounting offices and contains the following:

1. General information of the farm

2. Type of occupation (tenure)

3. Labor input

4. Number and value of livestock

5. Livestock purchases and sales

6. Costs

7. Land and buildings, dead-stock and circulating capital

8. Debts

9. Value added tax

10. Grants and subsidies

11. Production

12. Quota

13. Compensations in arable farming

Farther to other types of information which are presented in physical measures only, the data collected by FADN refer to assets, liabilities, revenues and expenses of the farms in the sample and is depicted in reports similar to balance sheets and income statements. Since many European farms do not give valid financial statements and when they do these statements are not directly comparable between countries, FADN had to develop and put in practice detailed guidelines and resolve both specific and general farm accounting issues. In this way, the "Farm Return" (Table 1) has exploited to a level of comprehensiveness comparable to the national accounting frames of countries like Spain, Greece or Italy.

Comparing FADN and IAS 41: Attempting to consistent FADN principles with those of IAS 41 we trace the valuation of assets, expenses and their presentation in the financial statements.

Valuation of assets: FADN is aligned with IASC' state as employs market prices for the valuation on nonmonetary assets. Particularly, livestock is valued at prices prevailing at beginning and ending of the accounting period. Land valuation is also based on the market price regarding location, quality and use, deducted any related development cost. Depreciable fixed asset such buildings and machinery are valued at replacement cost basis similarly, depreciation is calculated on replacement cost in the case of no existence replacement prices FADN updates acquisition cost with price indices. Farm stock is valued at realizable value at the balance sheet date without of deduction of sale costs. Plantations of permanent crops are valued at their historical cost.

Although IAS 41 requires biological assets to be measured at fair value less estimated point-of sale-costs providing a superior conceptuality FADN seems to be in line with IAS 41 since market prices reflect a more realistic approach while indicate also fair view.

IASC framework sustains a neutral policy keeping at measurement choices as vehicle of truly enterprising transactions. FADN similarly for the sake of simplicity adopts current values while valuation at replacement values maintains a uniform-data-rule for statistical purposes. Also the treatment of cumulative changes in current values comes into question since FADN includes all holdings gains of losses without any further disclose in owners' equity while IAS 41 mentions agriculture produce and biological asset so other IASs covering other assets (IAS 15 and 16) may be properly included.

Further diversion between FADN and IAS 41 is that FADN uses year-end prices (through market prices) for both livestock and inventories granting a more practical approach while the valuation of ending inventories at fair value, at the point of harvest by IAS 41 introduces practical difficulties because of differentiation in harvest time of agriculture production and the related market price fluctuation (e.g., using FIFO). In addition this approach may be proved confusing at the point of windfall valuations of agriculture production.

Expenses: FADN set out four broad categories of expenses marked specific costs, overheads, external factors and depreciation associated to type of farm, specific costs refer to seeds and plants, fertilizers crop protection and other crop costs, feed or other livestock costs. Overheads include machinery, building costs, contract work, energy and other direct inputs. 
Table 1: Farm return questionnaire

\begin{tabular}{|c|c|}
\hline Table A & $\begin{array}{l}\text { General information: } \\
\text { Identification and classification of the farm }\end{array}$ \\
\hline \multirow[t]{2}{*}{ Table B } & Type of occupation. \\
\hline & Breakdown of the farm area: owned, rented or sharecropped \\
\hline \multirow[t]{2}{*}{ Table C } & Labor: \\
\hline & $\begin{array}{l}\text { All labor, paid and unpaid (but excluding labor used on work under contract), which has contributed to work on the farm } \\
\text { during the accounting year. }\end{array}$ \\
\hline \multirow[t]{2}{*}{ Table D } & Number and value of livestock: \\
\hline & Opening and closing valuations (in number and value) and average number of livestock \\
\hline \multirow[t]{2}{*}{ Table E } & Livestock purchases and sales: \\
\hline & The value of such transactions together with the value of any farmhouse consumption of livestock \\
\hline \multirow[t]{2}{*}{ Table F } & Costs: \\
\hline & Value of all non-capital inputs used in the production of non-capital products during the accounting year. \\
\hline \multirow[t]{2}{*}{ Table } & Gland and buildings, dead stock and circulating capital. \\
\hline & Includes production, replacement or major repair of any fixed assets by the farms own resources valued on a cost basis. \\
\hline \multirow[t]{2}{*}{ Table H } & Debts: \\
\hline & Opening and closing valuations of short-, medium- and long-term loans \\
\hline \multirow[t]{2}{*}{ Table I } & Value added tax: \\
\hline & The VAT system applying and in certain cases VAT payments and receipts \\
\hline \multirow[t]{2}{*}{ Table J } & Grants and Subsidies: \\
\hline & $\begin{array}{l}\text { Defined as specific payments made directly to the farm business from public funds, excluding } \\
\text { those for investment in land, plant, machinery and equipment. }\end{array}$ \\
\hline \multirow[t]{2}{*}{ Table K } & Production (crops and animal products, livestock excluded): \\
\hline & The area, quantity and value of all crops, animal products and other activities \\
\hline \multirow[t]{2}{*}{ Table L } & Quotas and other rights: \\
\hline & Quotas and other rights included those acquired free if they can be traded separately from linked land. \\
\hline \multirow[t]{2}{*}{ Table M } & Direct payments for arable crops and beef: \\
\hline & $\begin{array}{l}\text { Detailed data concerning CAP arable crops area payments (Regulation (EC) } n^{\circ} 1251 / 99 \text { ) and direct payments for beef } \\
\text { (Regulation EC) } n^{\circ} 1254 / 99 \text { ) }\end{array}$ \\
\hline \multirow[t]{2}{*}{ Table N } & Details of purchases and sales of livestock: \\
\hline & $\begin{array}{l}\text { Purchases and sales per categories of livestock. The sub-totals of purchases and sales per animal species (equines, cattle...) } \\
\text { are registered in Table E. }\end{array}$ \\
\hline
\end{tabular}

Source: http://ec.europa.eu/agriculture/rica/collect_en.cfm

External factors include wages, rent and interest costs. FADN does not take into account the remuneration paid to the farmer as expense of farm this condition is also hold for any social charge in favor of farmer. Granted that in more Greek farms, family workforce is the major and settled parameter this is of considerable magnitude.

Specific costs and Overhead costs are recorded on accrual basis while external factors are valued on cash basis Costs related to consumption by farm itself (livestock, other outputs) are valued at realizable value. On the other hand IASC by IAS 41 does not also mention at all family workforce even as some form of "opportunity cost" (Argiles and Slof, 2001) while all expenses to be reported on accrual basis. Both FADN and IAS 41 seem to be in line but there are disparities that not fulfill effectively a realistic view. For the sake of consistent approach the accrual basis by IAS 41 can assimilate departures providing uniformity in information procedure.

Financial statement presentation: The Fig. 1 depicts the structure of balance sheet drawn by FADN. The asset side accommodates a restricted number of items strictly related to farming activity without further mention to other collateral activities, similarly on the liability side only three items strictly also relative to farming activity are reported as long and short term loans and owners' equity or net worth, for FADN expression «loan» includes payable and debts general. In accordance to IASC frame FADN should be more detailed getting at more informative reliable state.

\begin{tabular}{|l|}
\hline ASSETS \\
\hline Fixed assets \\
\hline Land and permanent crops \\
Buildings \\
Machinery \\
Breeding livestock \\
\hline Current assets \\
\hline Non-breeding livestock \\
Stock agricultural products \\
Other circulating capital \\
\hline NET WORTH \\
\hline LIABILITIES \\
\hline Long- and medium-term loans \\
\hline Short-term loans \\
(The layout of the balance sheet in the FA
\end{tabular}

Fig. 1: FADN balance sheet 


\begin{tabular}{|l|}
\hline +Total output \\
\hline + Subsidies on production and costs \\
\hline - Intermediate consumption \\
\hline a) Specific costs \\
\hline Seeds and plants \\
Fertilisers \\
Crop protection \\
Other crop specific costs \\
Feed grazing livestock \\
Feed pigs and poultry \\
Other livestock specific costs \\
\hline b) Overheads \\
\hline Machinery and building costs \\
Energy \\
Contract work \\
Other direct inputs \\
\hline - Taxes and VAT balance \\
\hline = Gross farm income or Gross \\
value added \\
\hline - Depreciation \\
\hline = Farm net value added \\
\hline +Investment grants and subsidies \\
\hline - Extemal factors \\
\hline Wages paid \\
Rent paid \\
Interest paid \\
\hline = Family farm income \\
(The layout of the income statement according to EU regulation) \\
\hline
\end{tabular}

Fig. 2: FADN income statement

IAS 41 holds more explicit entries on the face of balance sheet readable in the context of IASC standards but also strictly related to agriculture activities and would therefore FADN should be complied with IAS 41 as the core content of both remain in line.

The Fig. 2 shows the structure of Income Statement reported by FADN. In a similar way the Income Statement in not entirely completed since revenues and expenses not related to agriculture activity are not reported in it. Further its format seems to be organized by nature of the revenues and expenses fit into one of the format provided in the IV the directive and IAS 1. IAS 41 and Exposure draft (E65) support a similar classification by nature, (no conflicts with FADN). However the final version of the standard greatly support the classification by-function as reveal the cost of sales and gross profit while maintain the distinction of the holding gains realizing by changes in the fair value of biological assets. FADN does not support alike splitting but in the context of notes it would disclose this information.

\section{CONCLUSION}

This study approaches a stochastic comparison in order to show that agriculture accounting data can be an instrument of detailed guidelines for agriculture accounting.
In preceding these guidelines it is needed to resolve general accounting issues. FADN as informative mean representing CAP in Europe had to make efforts to obtain standardized information based on sound accounting principles. IASC on the other hand provides these sound accounting principles.

So in the ground of mutual compatible frame of FADN with IASC (IAS 41) we identified some aspects of accounting choices made by FADN which deviate from accounting principles found in the IASC context:

- FADN does not report all assets, liabilities and owner's equity on the balance sheet; many of the items shown are not disclosed in detail

- Not all revenues and expenses are reported on the income statement; many of the items shown are not disclosed in sufficient detail

- Not all revenues and expenses are defined on an accrual basis

- Holding gains due to changes in the market price of assets are defined in revenues and not disclosed distinctively

Through articulation of IAS 41 some aspects arrayed as follow:

- valuation of ending inventories of agricultural produce at fair value at the point of harvest might be unpractical and complicated

- the peculiar difficulties related to the remuneration of family workforce are not addressed

In practice, the key issue and challenge is the availability and the processing of Agriculture Management Plans (AMPs) and their updates through accounting information provided by financial statements enabling decision-making or allow the optimal allocation of resources.

Finally, beyond book-keeping farms require relatively new agriculture management plans (Penttinen and Rantala, 2008). So the information content perspective of agriculture accounting stresses the use of accounting numbers in decision making policy sustaining EU/CAP and fulfilling the role of standard-setting body.

\section{REFERENCES}

Allen, R., 1994. Farm potential: High tech leads the average farmer's know-how. Texas Bank., 88: 26.

Argiles, J. and E. Slof, 2001. New opportunities for farm accounting. Eur. Account. Rev., 10: 361-383. 
Andre, F., 1987. Towards a revival of economic education of farmers. Rural Econ., 177: 53-56.

Booth, P. and R. Walker, 2003. Valuation of SGARAS in the wine industry: Time for sober reflection. Aus. Account. Rev., 13: 52-60.

Bronstien, B.F., 1995. Group seeking to bring more farmers into line on financial reporting. Am. Bank., 27: 8 .

Burnside, A., 2005. IAS 41 and the forest industry. Goteborg University, School of Economics and Commercial Law, Bachelor Thesis, pp: 56.

CEC., 1997. Data definitions and instructions for the FADN farm return. Community Committee for the Farm Accountancy Data Network, RI/CC 1256 prov.

CEC., 1998. Definitions of variables used in FADN standard results. Community Committee for the Farm Accountancy Data Network, RI/CC 882 Rev.6.

Colwell, M. and R. Koroluk, 1990. Differences in farm incomes using cash or accrual accounting methods on Canadian crop farms and implications for farm management decision making. Can. J. Agric. Econ., 38: 655-665.

Crane, L.M. and D.J. Leatham, 1995. External equity financing in agriculture via profit and loss sharing contracts: A proposed financial innovation. Agribusiness, 11: 223-23.

Csajbok, I., 2009. Analysis of the accounting system of the farm accountancy data network. 4th Aspects and Visions of Applied Economics and Informatics, www.agris.fao.org.

Elad, C., 2004. Fair value accounting in the agricultural sector: Some implications for international accounting harmonization. Eur. Account. Rev., 3: 621-641.

Epstein, B.J. and A.A. Mirza, 2003. Interpretation and application of international financial reporting standards 2005. John Wiley and Sons, USA.

IASC., 2000. International accounting standard IAS 41: Agriculture. Proceeding of the International Accounting Standards Committee, London International Accounting Standard 2002. IAS 41 Agriculture. European Union, Brussels.

Karanikolas, P. and. N. Martinos, 2007. The modernization process in Greek agriculture: The case of investment aid. Agric. Econ. Rev., 8: 37-49.

Kroll, J.C., 1987. The new accounting: The lost opportunities. Rural Econ., 180: 20-25.

Luening, R.A., 1989, Farms records can improve profitability. United States Department of Agriculture, Farm Management: How to Achieve Farm Business Goals. Washington, Government Printing Office, US, pp: 103-112.
Olsson, R., 1988. Management for success in modern agriculture. Eur. Rev. Agric. Econ., 15: 239-259.

Pavlos, D.P., 2004a. A brief overview of agriculture in Greece. Remote Sensing for Agriculture and the Environment, GAIA Centre/OECD, ISBN: 96088000-8-0.

Pavlos, D.P., 2004b. Liberalization and the Future of Agricultural Policies, the Greek view. Ministry of Rural Development and Food (GR).

Pellerin, J.L., 1985. Farmers and keeping the records. French Revue Account., 154: 26-32.

Penttinen, M. and O. Rantala, 2008. The International Financial Reporting Standards (IFRS) accounting system as applied to forestry. Working papers of the Finnish Forest Research Institute. http://www.metla.fi/julkaisut/workingpapers/2008/ mwp093.htm

Poppe, K.J. and J.A. Breembroek, 1992. The assessment of a farm's financial situation with a report writer. Tijdschrift Voor Sociaalwonde, 7: 49-70.

Poppe, K.J., 1991. Information needs and accounting in agriculture. Agric. Econ. Res. Institute LEI, 444: 1-51.

Poppe, K.J., 2000. Towards consistent micro-and macro level economic statistics. National Accounts$\begin{array}{lll}\text { Agriculture } & \text { OECD, } & \text { No. }\end{array} 6347$ STD/NA/AGR(2000)8.

Poppe, K.J., 2005. Microeconomic Data on Farm Diversification, Rural Businesses and Intragenerational Transfer. Agricultural Economics Research Institute (LEI), The Hague.

Psaltopoulos, D. and. E. Balamou, 2005. Modeling the effects of Trade policy scenarios on Multifunctionality: A social accounting matrix approach. Thematic Network on Trade Agreements' and European Agriculture, ENARPRI.

Rezitis, A.N., K. Tsiboukas and S. Tsoukalas, 2002. Measuring technical efficiency in the Greek agricultural sector. Applied Econ., 34: 1345-1357.

Seger, D.J. and D.A. Lins, 1986. Cash versus accrual measures of farm income. North Central J. Agric. Econ., 8: 219-226.

Tonea, E., 2001. Does the accounting information influence the farm prosperity? 